\title{
Self-esteem and Symptoms of Mental Disorder in the Adolescence: Associated Variables
}

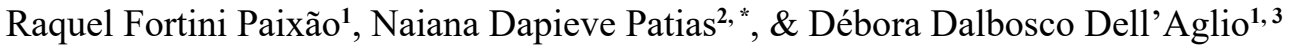 \\ ${ }^{1}$ Universidade Federal do Rio Grande do Sul, Porto Alegre, RS, Brasil \\ ${ }^{2}$ Faculdade Meridional, Passo Fundo, RS, Brasil \\ ${ }^{3}$ Unilasalle, Canoas, RS, Brasil
}

\begin{abstract}
The objective of this study was to investigate the relationships between symptoms of mental disorders and self-esteem of adolescents, as also their association with sex, age and family configuration. Participants were 359 adolescents aged 13 to 19 years $(\mathrm{M}=15.77, \mathrm{SD}=1.40)$, students from public schools. The instruments were the Rosenberg Self-Esteem Scale and the Self-Reporting Questionnaire. Descriptive analyzes, Spearman correlation test, Mann-Whitney U test and Kruskal-Wallis test were performed. The results indicated a lower average in the symptoms of mental disorder among the boys, but no differences were observed by sex, age or family configuration regarding self-esteem. There was a significant negative correlation between symptoms of mental disorders and self-esteem, confirming the relationships between these variables. Limitations and suggestions for further studies are discussed.
\end{abstract}

KEYWORDS: adolescence, self-esteem, mental disorders, family

\section{Autoestima e Sintomas de Transtornos Mentais na Adolescência: Variáveis Associadas}

\begin{abstract}
RESUMO - O objetivo deste estudo foi investigar relações entre sintomas de transtornos mentais e autoestima de adolescentes, bem como sua associação com sexo, idade e tipo de configuração familiar. Participaram 359 adolescentes de 13 a $19 \operatorname{anos}(M=15,77 ; D P=1,40)$, estudantes de escolas públicas. Foram utilizadas a Escala de Autoestima de Rosenberg e o instrumento Self-Reporting Questionnaire. Foram realizadas análises descritivas, teste de correlação de Spearman, U de Mann-Whitney e Kruskal-Wallis. Os resultados indicaram menor média nos sintomas de transtorno mental entre os meninos, mas não foram observadas diferenças por sexo, idade ou configuração familiar quanto à autoestima. Houve correlação negativa significativa entre sintomas de transtornos mentais e autoestima, confirmando as relações entre essas variáveis. Limitações e sugestões para novos estudos são discutidas.
\end{abstract}

PALAVRAS-CHAVE: adolescência, autoestima, transtornos mentais, família

Self-esteem and mental health in adolescence are important variables that have been related to healthy or risky experiences in this important period of development (Steiger, Allemand, Robins, \& Fend, 2014). Self-esteem is understood as a set of feelings and thoughts of the individual in regard to their own value, competence, confidence, adequacy and ability to face challenges, which impacts on a positive or negative attitudes toward oneself (Rosenberg, 1965). It is considered an important factor that influences the way people perceive, feel and respond to the world. High or low self-esteem is related to a person's lifelong experiences, such as those related to affection, love, appreciation, success or failure (Schraml, Perski, Grossi, \& Somonsson-Sarnecki, 2011). Several authors consider that a positive self-esteem is fundamental for the person to develop the maximum of their abilities from the earliest age (Bean \& Northrup, 2009; Hair \& Graziano, 2003; Martínez, Roselló, \& Toro-Alfonso, 2010).

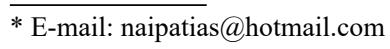


Due to cognitive, social and affective changes, the adolescent is more susceptible to variations in self-esteem. For Moksnes, Moljord, Espnes and Byrne (2010), self-esteem is important for an adolescents' self-understanding and is likely to be a buoyant and dynamic construct, susceptible to internal and external influences during adolescence.

Some studies associate low or negative self-esteem with problems in the development of adolescents. Veselska et al. (2009) investigated the association between self-esteem, resilience and various forms of risk behavior among adolescents. The data revealed that negative self-esteem seems to play an important role in the risk behavior of boys and girls. In this study, negative self-esteem, for example, was a risk factor for cigarette and marijuana use. Another study (Kavas, 2009) investigated the relationship between self-esteem and health risk behavior such as the use of cigarette, alcohol and other drugs in a group of Turkish adolescents. The study revealed that self-esteem was negatively associated with alcohol and illicit drug use. Comparisons between the genders did not indicate differences in the self-esteem scale, but male adolescents reported significantly greater use of cigarettes and drugs.

Other studies have related self-esteem to different aspects of the emotional development. Adolescents with low selfesteem are almost seven times more likely to present minor psychiatric disorders (subjective experience of non-specific malaise with physiological and psychological repercussions) compared to those with high self-esteem. Those who are not satisfied with their lives present 2.22 times more the disorders investigated in comparison to those who are satisfied. Moreover, the study revealed that boys have a lower risk for the development of mental disorders when compared to girls (Avanci, Assis, Oliveira, Ferreira, \& Pesce, 2007). Martínez et al. (2010) observed the relationship between self-esteem and depression in adolescents and young adults, and the higher the levels of depressive symptoms, the lower the levels of self-esteem. Low self-esteem, in this sense, explained $25 \%$ of the symptoms of depression in the study participants. In the longitudinal study of Steiger et al. (2014), developed for 23 years, they observed the importance of adolescent self-esteem for mental health effects in adulthood, as a correlation was found between low self-esteem in adolescence and depressive symptoms in adult life. The association between self-esteem and depression was also found in the study by Li, Delvecchio, Di Riso, Salcuni and Mazzeschi (2015), with adolescents from three countries of different cultures.

Several studies have associated mental health and selfesteem (Avanci et al., 2007; Barry, Grafeman, Adler, \& Pickard, 2007; Glashouwer, Vroling, Jong, Lange, \& Keijser, 2013; Raedt, Schacht, Franck, \& Houwer, 2006 Sowislo \&
Orth, 2013). The results indicate that self-esteem influences the mental health of adolescents. Sowislo and Orth (2013) have observed, for example, that the effect of self-esteem on depression was significantly stronger than the effect of depression on self-esteem. In addition, a correlation between anxiety and self-esteem was also observed.

Self-esteem was also considered an important mediator for perceived social support and suicidal ideation (Kleiman \& Riskind, 2013), and perceived social support would result in increased self-esteem, which would alleviate suicidal ideation. Falkenbach, Howe and Falki (2013) investigated associations between self-esteem, aggression, narcissism and psychopathy, and observed that the instability of selfesteem was positively associated with aggression. Still, important studies have considered the stability and levels of self-esteem, demonstrating that fluctuations of self-esteem can arise from contextualized experiences and immediate feelings of eigenvalue, i.e., self-esteem depends on how people feel at the moment facts occur (Kernis, 2005; Kernis et al., 1998). These studies suggest that people who are more vulnerable to depression, for example, are more likely to present fluctuations of the feelings of self-worth, particularly in response to negative events.

In addition to the association between self-esteem and mental disorders, the quality of family relationships has also been associated with self-esteem levels. Brodski (2010) found a correlation between self-esteem and emotional abuse in the family environment in a study with university students from southern Brazil. The participants who reported experiencing emotional abuse showed high scores of negative affect (eg, impatient, distressed) and low scores of self-esteem, the positive affect (eg friendly, caring) being related to life satisfaction. Another study (Bravo \& Tapia, 2006) involving Chilean adolescents on the relationship between self-esteem, attachment and depression, found a positive correlation between availability and attachment to parents and positive self-esteem, and a lower perception of availability of attachment figures was associated with a higher rate of depression. The study by Avanci et al. (2007) indicated that the family relationship is related to the development of mental disorders. For example, adolescents who had family relationships permeated by discussion, separation, or remarriage of the father or mother were more likely to develop some kind of mental disorder than adolescents with few family difficulties.

Therefore, the objective of this study was to investigate the relationships between symptoms of mental disorders and self-esteem of adolescents living with their families and their association with variables such as gender, age and type of family configuration. 


\section{METHOD}

\section{Participants}

A total of 359 adolescents of different family configurations, aged between 13 and $19(\mathrm{M}=15.77, \mathrm{SD}=$ 1.40), of both sexes, students within the 7th grade and the 3rd year of high school from public schools in the city of Porto Alegre, Brazil, participated in the study. The sample was constituted randomly from the draw of public schools of the city, according to the list made available by the Secretary of Education. For each selected school, a class of each grade was drawn to participate. The collection was done in 13 schools of different districts of the city, being 12 of them state schools and one municipal. In relation to the family configuration variable, 201 adolescents belonged to nuclear families, 109 to single-parent families and 49 to reconstituted families, one adolescent to an adoptive family and 16 adolescents belonged to other settings (lived with companion, grandparents, uncles, etc.). The 17 participants with different family configurations (in an adoptive family, living with grandparents or partners) were excluded from the study sample.

\section{Instruments}

Brazilian Youth Questionnaire (QJB version II; Dell'Aglio, Koller, Cerqueira-Santos, \& Colaço, 2011). The instrument is composed of 77 questions, some of which multiple choice and others are in Likert format of five points on intensity and frequency, which aim to investigate risk factors and protection in adolescence. For the analyzes carried out in this study, we used the sociodemographic data questions of the questionnaire and question 74, which includes the Rosenberg Self-Esteem Scale (EAR; Rosenberg, 1965), revised for Brazil by Hutz and Zanon (2011). The EAR contains 10 items on a five-point Likert scale, ranging from 10 to 50 points. As for the family configuration, from the sociodemographic questions, we observed with whom the adolescent lived, thus determining if the family was nuclear (lives with father and mother), single parent (only with the father or mother), reconstituted (with the presence of stepfather or stepmother) or other settings (when living with other relatives, grandparents or partner).

Self-Reporting Questionnaire (SRQ-20). It was developed by Harding et al. (1980) and validated for Brazil by Mari and Williams (1986). The instrument is composed of 20 questions assessing psychic and somatic screening of mood, anxiety and somatization disorders, also called minor or common mental disorders (Gonçalves, 2016). The symptoms in SRQ-20 refer to insomnia, fatigue, irritability, forgetfulness, difficulty concentrating and somatic complaints. Items are answered in a dichotomous way (0 $=$ No, $1=$ Yes), such as: "do you often have headaches", "sleep badly", "feel unhappy", "find it difficult to enjoy your daily activities", among others. The scores of the sum of the items can be interpreted by a quantitative analysis in which 0 would be no probability, and 20, extreme probability for common mental disorder. The cut-off point, for both the female and the male, is $7 / 8$, with the score 8 considered as suspect for mental disorder (Gonçalves, 2016). However, further research is needed for a diagnosis, since SRQ is a screening tool. The psychometric properties of the SRQ-20 were evaluated by Santos, Araújo and Oliveira (2009), who indicated a coefficient of internal consistency of 0.80 .

\section{Data Analysis}

Descriptive analyzes were performed on SRQ-20 scores and the Rosenberg Self-esteem Scale. In addition, in order to compare means in the instrument scores in relation to gender, we used Mann-Whitney U test, considering that the data distribution did not show normality. With the analysis of variance (Kruskal-Wallis) we aimed to verify if there was a statistically significant difference between symptoms of mental disorders, self-esteem and type of family configuration (nuclear, reconstituted and single-parent). The Spearman correlation test $(\rho)$ was used to verify correlation between age, symptoms of mental disorders and self-esteem.

\section{Procedures and Ethical Considerations}

The major project, from which this study is derived, was approved by the Research Ethics Committee of the university where the research was carried out, under the number 2009060. For the collection of data, we made contact with the management team of each institution, requesting the agreement of the schools to carry out the research. The students were invited to participate, guaranteeing that the participation in the research was voluntary, that personal information was confidential and withdrawal was possible at any time. Soon after, we requested that the parents or guardians signed of the Informed Consent Form (ICF), as well as the signing of the Term of Assent (TA) by the adolescents. The questionnaires were taken collectively in a classroom, with the maximum duration of 60 minutes. 


\section{RESULTS}

The averages and standard deviations of the instruments used are presented in Table 1, by gender and family configuration.

The descriptive analysis of the 20 items of SRQ-20, which evaluates symptoms of mental disorders, indicated good internal consistency (Cronbach's alpha $=0.82$ ). For the survey of the scores, we added the points in each answered item. The participants of this study obtained an average of 4.87 ( $\mathrm{SD}=4.04$ ) points, ranging from zero to 17 . We analyzed the scores considering the socio-demographic variables of gender, family configuration and age.

Considering that the distribution of the SRQ-20 scores did not present a normal distribution, the analyzes were performed using non-parametric statistics. The MannWhitney test indicated a significant difference by sex ( $\mathrm{Z}$ $=4.35, \mathrm{p}<0.001)$, with boys presenting a lower mean of symptoms $(\mathrm{M}=3.59, \mathrm{SD}=3.52)$ than girls $(\mathrm{M}=5.50$, $\mathrm{SD}=4.14)$. The analysis of variance (Kruskal-Wallis) did not present a statistically significant difference in the symptoms of mental disorder between types of family configuration (nuclear, reconstituted and single-parent). Finally, Spearman's correlation test $(\rho)$ did not indicate a significant correlation between the age of the adolescents and the number of symptoms.

Regarding the Rosenberg Self-esteem Scale, it presented good internal consistency (Cronbach's alpha $=0.90$ ). For the survey of the scores, we added the points in each answered item. The participants in this study had an average of 41.55
$(\mathrm{SD}=7.38$ ) points in the RAS, ranging from 10 to 50 . We analyzed the scores considering the socio-demographic variables of gender, family configuration and age.

Considering that the distribution of EAR scores also did not present a normal distribution, the analyzes were performed using non-parametric statistics. The MannWhitney $U$ test did not indicate a statistically significant difference by sex. Regarding the family configuration variable, the analysis of variance (Kruskal-Wallis) did not present a statistically significant difference in relation to the self-esteem scores and the family configuration types (nuclear, reconstituted and single-parent). Furthermore, Spearman's correlation test $(\rho)$ did not indicate a significant correlation between adolescents' age and self-esteem. However, a significant negative correlation was observed between SRQ and self-esteem $(\rho=-0.44, p<0.001)$.

Table 1. Means and Standard Deviation of the instruments by Sex and Family Configuration

\begin{tabular}{llcc}
\hline & & SRQ-20 & Self-Esteem \\
\hline \multirow{4}{*}{ Sex } & Boys $(\mathrm{n}=119)$ & $3.59(\mathrm{SD}=3.52)$ & $42.19(\mathrm{SD}=7.16)$ \\
& Girls $(\mathrm{n}=240)$ & $5.50(\mathrm{SD}=4.14)^{*}$ & $41.22(\mathrm{SD}=7.49)$ \\
& & & \\
Family & Nuclear $(\mathrm{n}=201)$ & $4.84(\mathrm{SD}=3.87)$ & $41.9(\mathrm{SD}=7.08)$ \\
Configuration & Reconstituted $(\mathrm{n}=49)$ & $4.84(\mathrm{SD}=4.68)$ & $41.06(\mathrm{SD}=7.33)$ \\
& Single Parent $(\mathrm{n}=109)$ & $4.94(\mathrm{SD}=4.09)$ & $41.06(\mathrm{SD}=7.95)$ \\
\hline
\end{tabular}

$* \mathrm{p}<0.001$

\section{DISCUSSION}

The study investigated the self-esteem and symptoms of mental disorder of adolescents living with their families, relating to individual variables (gender and age) and family variables (type of family configuration). As we previously observed, the types of family configurations (nuclear, single parent and reconstituted) had no association with self-esteem or with the symptoms of mental disorder in the investigated adolescents. This result is in agreement with the results of other researches which show that the composition of the family is not as important in the development of the children as the quality of the relationships established (Mota, 2016; Oliveira, Siqueira, Dell'Aglio, \& Lopes, 2008; Sbicigo \& Dell'Aglio, 2012; Wagner, Ribeiro, Arteche, \& Bernholdt, 1999). On the other hand, the quality and quantity of negative family life events may be particularly detrimental to the development of children and adolescents as well as how functional family relationships would favor the expression of positive psychological characteristics in adolescence
(Wagner et al., 1999) . These aspects should be investigated in future studies.

Regarding the individual variables, we observed no effect of age on the symptoms of mental disorder, but there was a gender difference, in which the boys had a lower average of symptoms when compared to the girls. Regarding age, this result contradicts a national study (Lopes et al., 2016), carried out with 74,589 school-aged adolescents between 12 and 17 years of age, indicating changes during the development, with a higher prevalence of mental disorders in adolescents aged 15 to 17 years, when compared to the younger ones. However, the study indicated that the prevalence of mental disorder in girls is higher when compared to boys, similar to the result found here. Several studies have indicated that females constitute a risk for psychiatric disorders, while boys are less likely to have mental health problems (Avanci et al., 2007; Souza et al., 2010). For Carvalho et al. (2011), the prevalence of negative indicators of mental health, such as 
sadness, loneliness, suicidal thoughts, sleeping difficulties and suicidal ideation, is higher among girls. However, diverse results can be found in studies investigating sex and mental health. In the longitudinal study by Oldehinkel and Ormel (2015) with Dutch adolescents, although the overall risk of depression was about twice as high for girls, the risk for mental illness associated with exposure to childhood adversities was comparable for both sexes. In the study by Sá, Bordin, Martin and Paula (2010), there was a predominance of boys with internalizing mental health problems, although the result may have been influenced by the composition of the sample, with younger children. Thus, considering that there are contradictions in the results of different studies, it seems that there is need to better investigate the question of the influence of the sex on the symptoms of mental disorder in adolescence.

Regarding self-esteem, the results of this study did not indicate differences by sex and age, as other researchers have found (Bandeira, Quaglia, Bachetti, Ferreira, \& Souza, 2005; Hyde, 2005). However, this result is different from that found in the longitudinal research conducted in Spain with 90 adolescents aged 13 to 21 years (Sánchez-Queija, Oliva, \& Parra, 2016), that investigated the development of self-esteem through adolescence and emerging adulthood, and the relationships with family and friends. The study indicated that, in early adolescence, there is no gender difference in this construct, but over time, in the middle adolescence, self-esteem tends to be greater in boys, and that difference disappears in emerging adulthood. The authors explain that the difference in biological changes during puberty may influence the self-esteem. However, they mention that the social context also has influence, because, initially, self-esteem may be related to the maternal care given to adolescents and, later, to peer influences. Feliciano and Afonso (2012), as well as Moksnes et al. (2010) and von Soest, Wichstrøm and Kvalem (2016), also found a significant difference by sex when they investigated the selfesteem of adolescents, finding higher self-esteem among the boys. Assis et al. (2003) qualitatively investigated the feeling the teenager has of itself, its values and competence. They noted, in their study, that boys mentioned more words that reflected positive behavioral attributes, such as tranquility and balance, in addition to defining themselves based on personal competence more than girls. However, although it is important to analyse gender and gender stereotypes in the psychological phenomena of adolescence, since boys and girls experience the changes in this period in different ways, there is no consensus about the role of sex in the construction of self-esteem in adolescence (Hutz, Zanon, \& Vazquez, 2014), an aspect that should be better investigated in future studies.

On the association between self-esteem and symptoms of mental disorder, the results indicated a significant negative correlation between the variables. This association confirms the results from previous studies, where self-esteem levels were associated with psychological and behavioral phenomena such as suicidal ideation, stress, life satisfaction, well-being, academic performance, among others (Barry, Grafeman, Adler, \& Pickard, 2007; Carranza, You, Chhuon, \& Hudley, 2009; Freire \& Tavares, 2011; Sowislo et al., 2013; Steiger et al., 2014). The importance of self-esteem, especially in the teenage years, is considerably large, as it can affect one's way of being, feeling and acting in the world and relating to other people (Freire \& Tavares, 2011). According to Assis and Avanci $(2004$, p. 18) "self-esteem is perhaps the most critical variable that affects the successful participation of a teenager with others in a project. Young people with low self-esteem, develop mechanisms that are likely to distort the communication of their thoughts and feelings and hinder the group integration". This variable has been relevant in several psychopathological settings and frequently associated with conditions such as depression, anxiety, social phobia, delinquency, etc. (Gómez-Bustamante \& Cogollo, 2010).

It is important to take into account that adolescence is a period of development in which physical, cognitive and social changes occur (Schoen-Ferreira, Aznar-Farias, \& Silvares, 2010; Steinberg \& Lerner, 2004; Surjadi, Lorenz, Wickrama, \& Conger, 2011), and the adolescent starts to play another role before his family, being more participative and presenting greater autonomy. For this, emotional integrity becomes important, since healthy levels of self-esteem and mental health can impel a performance more adaptive to the demands of the environment during that period.

\section{FINAL CONSIDERATIONS}

The results of this study demonstrate that among the personal and family variables analyzed, only sex was associated with symptoms of mental disorder. The other variables had little impact on self-esteem and symptoms of mental disorder in the sample investigated, although these constructs are associated. We observed that the different family settings investigated did not show significant relation with mental health and self-esteem. A mapping of national and international scientific production on separation/divorce, remarriage and single parenting has demonstrated that different family configurations are not related to significant changes or consequences on the development of children and adolescents (Oliveira et al., 2008). Thus, we understand that social changes have generated a growing demand for 
new alternatives to establish rules of family and social functioning, favoring that these new nuclei continue to fulfill their basic function of protection, care and development of children (Wagner \& Levandowski, 2008). We can hypothesize that the type of relationship established between family members and the quality of the bonds established are more important than the family configuration.

Moreover, we found a significant association between self-esteem and symptoms of mental disorder in adolescents, but we cannot conclude on the direction of this relationship, since the variables are complex and multidetermined. Thus, self-esteem and mental health are still important constructs to be studied, given the magnitude of the impact on people's lives, especially adolescents. Adolescents with mental health problems should be identified early in order to avoid, for example, the chronic course of the disease, which can lead to a compromised social performance. We emphasize the importance of giving visibility to these phenomena, through studies that contribute to constructing intervention programs to provide young people with more adequate conditions for an adulthood with well-being and quality of life.
Finally, there are some limitations to this study, since the sample investigated was composed of adolescents who lived with their families and belonged to lower social classes, that studied in public schools of the city of Porto Alegre located, predominantly, in a neighborhood of greater social vulnerability. Therefore, one cannot generalize the results for all adolescents. New studies comparing adolescents with different socioeconomic conditions and schooling would be interesting, to observe whether material resources and different life opportunities, for example, would have an impact on the analyzed variables. In addition, longitudinal studies and those with clinical samples could contribute relevantly, as they would allow monitoring of the changes and stability of self-esteem and symptoms throughout the development, as well as investigating more deeply the individual and family variables associated with different psychopathological scenarios in adolescence. Also, in order to better understand this topic, it would be interesting to assess how young people feel when positive or negative events occur, observing contextual aspects and, thus, being able to verify and understand the fluctuations in their selfesteem to better intervene.

\section{REFERENCES}

Assis, S., Avanci, J., Silva, C., Malaquias, J., Santos, N., \& Oliveira, R. (2003). A representação social do ser adolescente: Um passo decisivo na promoção da saúde. Ciência \& Saúde Coletiva, 8(3), 669-680. doi: 10.1590/S1413-81232003000300002

Assis, S. G., \& Avanci, J. Q. (2004). Labirinto de espelhos: Formação da autoestima na infância e na adolescência. Rio de Janeiro: Fiocruz.

Avanci, J. Q., Assis, S. G., Oliveira, R. V. C., Ferreira, R. M., \& Pesce, R. P. (2007). Fatores associados aos problemas de saúde mental em adolescentes. Psicologia: Teoria e Pesquisa, 23(3), 287-294.

Bandeira, M., Quaglia, M. A. C., Bachetti, L. S., Ferreira, T. L., \& Souza, G. G. (2005). Comportamento assertivo e sua relação com ansiedade, locus de controle e auto-estima em estudantes universitários. Estudos de Psicologia (Campinas), 22(2), 111121. doi: 10.1590/S0103-166X2005000200001

Barry, C. T., Grafeman, S. J., Adler, K. K., \& Pickard, J. D. (2007). The relations among narcissism, self-esteem, and delinquency in a sample of at-risk adolescents. Journal of Adolescence, 30, 933-942. doi: 10.1016/j.adolescence.2006.12.003

Bean, R. A., \& Northrup, J. C. (2009). Parental psychological control, psychological autonomy, and acceptance as predictors of self-esteem in Latino adolescents. Journal of Family Issues, 30(11), 1486-1504. doi: 10.1177/0192513X09339149

Bravo, L. G., \& Tapia, L. M. (2006). Relación entre autoestima, depresión y apego en adolescentes urbanos de La Comuna de Concepción, Chile. Terapia Psicológica, 24(1), 5-14.

Brodski, S. K. (2010). Abuso emocional: Suas relações com autoestima, bem-estar subjetivo e estilos parentais em universitários (Dissertação de Mestrado). Programa de PósGraduação em Psicologia, Universidade Federal do Rio Grande do Sul, Porto Alegre, RS, Brasil.
Carranza, F. D., You, S., Chhuon, V., \& Hudley, C. (2009). Mexican American students' academic achievement and aspirations: The role of perceived parental educational involvement, acculturation, and self-esteem. Adolescence, 44(174), 313- 333.

Carvalho, P. D., Barros, M. V. G., Santos, C. M., Melo, E. N., Oliveira, N. K. R., \& Lima, R. A. (2011). Prevalência e fatores associados a indicadores negativos de saúde mental em adolescentes estudantes do ensino médio em Pernambuco, Brasil. Revista Brasileira de Saúde Materno-Infantil, 11(3), 227-238. doi: 10.1590/S1519-38292011000300003

Dell'Aglio, D. D., Koller, S. H, Cerqueira-Santos, E., \& Colaço, V. (2011). Revisando o Questionário Juventude Brasileira: Uma nova proposta. In D. D. Dell'Aglio \& S. H. Koller (Eds.), Adolescência e juventude: Vulnerabilidade e contextos de proteção (pp. 259-270). São Paulo: Casa do Psicólogo.

Falkenbach, D. M., Howe, J. R., \& Falki, M. (2013). Using self-esteem to disaggregate psychopathy, narcissism, and aggression. Personality and Individual Differences, 54, 815820. doi: 10.1016/j.paid.2012.12.017

Feliciano, I. P., \& Afonso, R. M. (2012). Estudo sobre a autoestima em adolescentes dos 12 aos 17 anos. Psicologia, Saúde \& Doenças, 13(2), 252-265.

Freire, T., \& Tavares, D. (2011). Influência da autoestima, da regulação emocional e do gênero no bem-estar subjetivo e psicológico de adolescentes. Revista de Psiquiatria Clínica, 38(5), 184-188. doi: 10.1590/S0101-60832011000500003

Glashouwer, K. A., Vroling, M. S., Jong, P. J., Lange, W., \& Keijser, J. (2013). Low implicit self-esteem and dysfunctional automatic associations in social anxiety disorder. Journal of Behavior Therapy and Experimental Psychiatry, 44, 262-270. doi: 10.1016/j.jbtep.2012.11.005. 
Gómez-Bustamante, E. M., \& Cogollo, Z. (2010). Factores predictores relacionados con el bienestar general en adolescentes estudiantes de Cartagena, Colombia. Revista de Salud Pública, 12(1), 61-70. doi: 10.1590/S012400642010000100006

Gonçalves, D. M. (2016). Self-Reporting Questionnaire (SRQ). In C. Gorenstein, Y-P. Wang, \& I. Hungerbuhler (Eds.), Instrumentos de avaliação em saúde mental (pp. 82-86). Porto Alegre: Artmed.

Hair, E. C., \& Graziano, W. G. (2003). Self-esteem, personality and achievement in high school: A prospective longitudinal study in Texas. Journal of Personality, 71(6), 971-994.

Harding, T. W., De Arango M. V., Baltazar, J., Climent, C. E., Ibrahim, H. H., Ladrido-Ignacio, L., ....Wig, N. N. (1980). Mental disorders in primary health care: A study of their frequency and diagnosis in four developing countries. Psychological Medicine, 10(2), 231-241.

Hyde, J. A. (2005). The gender similarities hypothesis. American Psychologist, 60(6), 581-592. doi: 10.1037/0003066X.60.6.581

Hutz, C. S., \& Zanon, C. (2011). Revisão da adaptação, validação e normatização da Escala de Autoestima de Rosenberg. Avaliação Psicológica, 10(1), 41-49.

Hutz, C. S., Zanon, C., \& Vazquez, A. C. S. (2014). Escala de Autoestima de Rosenberg. In C. S. Hutz (Ed.), Avaliação em Psicologia Positiva (pp. 85-94). Porto Alegre: Artmed.

Li, J., Delvecchio, E., Di Riso, D., Salcuni, S., \& Mazzeschi, C. (2015). Self-esteem and its association with depression among Chinese, Italian, and Costa Rican adolescents: A cross-cultural study. Personality and Individual Differences, 82, 20-25. doi: 10.1016/j.paid.2015.02.036

Kavas, A. B. (2009). Self-esteem and health-risk behaviors among Turkish late adolescents. Adolescence, 44(173), 187-198.

Kernis, M. H. (2005). Measuring self-esteem in context: The importance of stability of self-esteem in psychological functioning. Journal of Personality, 73(6), 1569-1605. doi: 10.1111/j.1467-6494.2005.00359.x

Kernis, M. H., Whisenhunt, C. R., Waschull, S. B., Greenier, K. D., Berry, A. J., \& Herlocker, C. E., \& Craig, A. (1998). Multiple facets of self-esteem and their relations to depressive symptoms. Personality and Social Psychology Bulletin, 24, 657-668.

Kleiman, E. M., \& Riskind, J. H. (2013). Utilized social support and self-esteem mediate the relationship between perceived social support and suicide ideation. Crisis, 34(1), 42-49. doi: 10.1027/0227-5910/a000159.

Lopes, C., S., Abreu, G. A, Santos, D. F., Menezes, P. R., Carvalho, K. M. B., \& Szklo, M. (2016). ERICA: Prevalência de transtornos mentais comuns em adolescentes brasileiros. Revista de Saúde Pública, 50, 1-9. doi:10.1590/S015188787.2016050006690

Mari, J., \& Willians, P. A. (1986). A validity study of a psychiatric screening questionnaire (SRQ-20) in primary care in the city of São Paulo. British Journal of Psychiatry, 148, 23-26. doi: 10.1192/bjp.148.1.23

Martínez, B. I. V., Roselló, J., \& Toro-Alfonso, J. (2010). Autoestima y juventud puertorriqueña: Eficacia de un modelo de intervención para mejorar la autoestima y disminuir los síntomas de depresión. Revista Puertorriqueña de Psicología, $21,35-61$.

Moksnes, U. K., Moljord, I. E. O., Espnes, G. A., \& Byrne, D. G. (2010). The association between stress and emotional states in adolescents: The role of gender and self-esteem. Personality and Individual Differences, 49(5), 430-435. doi:10.1016/j. paid.2010.04.012
Mota, C. P. (2016). Individuação e coping em adolescentes de famílias tradicionais e divorciadas. Temas em Psicologia, 24(3), 1115-1128. doi: 10.9788/TP2016.3-16

Oldehinkel, A., \& Ormel, J. (2015). A longitudinal perspective on childhood adversities and onset risk of various psychiatric disorders. European Child \& Adolescent Psychiatry, 24(6), 641-650. doi: 10.1007/s00787-014-0540-0

Oliveira, D., Siqueira, A. C., Lopes, R. S., \& Dell'Aglio, D. D. (2008). Impacto das configurações familiares no desenvolvimento de crianças e adolescentes: Uma revisão da produção científica sobre separação/divórcio, recasamento e monoparentalidade. Interação, 12, 87-98. doi: 10.1590/S010279722014000100017

Raedt, R., Schacht, R., Franck, E., \& Houwer, J. (2006). Selfesteem and depression revisited: Implicit positive self-esteem in depressed patients? Behavior Research and Therapy, 44, 1017-1028. doi: 10.1016/j.brat.2005.08.003

Rosenberg, M. (1965). Society and the adolescent self-image. Princeton: Princeton University Press.

Sá, D. G. F., Bordin, I. A. S., Martin, D., \& Paula, C. S. (2010). Fatores de risco para problemas de saúde mental na infância/ adolescência. Psicologia: Teoria e Pesquisa, 26(4), 643-652.

Sánchez-Queija, I., Oliva, A., \& Parra, A. (2016). Stability, change, and determinants of self-esteem during adolescence and emerging adulthood. Journal of Social and Personal Relationships, s/v, 1-18. doi: 10.1177/0265407516674831

Santos, K. O. B., Araújo, T. M., \& Oliveira, N. F. (2009). Estrutura fatorial e consistência interna do Self-Reporting Questionnaire (SRQ-20) em população urbana. Cadernos de Saúde Pública, 25(1), 214-222. doi: 10.1590/S0102-311X2009000100023

Sbicigo, J. B., \& Dell'Aglio, D. D. (2012). Family environment and psychological adaptation in adolescents. Psicologia: Reflexão e Crítica, 25(3), 615-622. doi: 10.1590/S010279722012000300022

Schoen-Ferreira, T. H., Aznar-Farias, M., \& Silvares, E. F. M. (2010). Adolescência através dos séculos. Psicologia: Teoria e Pesquisa, 26(2), 227-234. doi: 10.1590/S010237722010000200004

Schraml, K., Perski, A., Grossi, G., \& Simonsson-Sarnecki, M. (2011). Stress symptoms among adolescents: The role of subjective psychosocial conditions, lifestyle and selfesteem. Journal of Adolescence, 34, 987-996. doi: 10.1016/j. adolescence.2010.11.010.

Souza, L. D. M., Ores, L., Oliveira, G. T., Cruzeiro, A. L. S., Silva, R. A., Pinheiro, R. T., \& Horta, B. L. (2010). Ideação suicida na adolescência: Prevalência e fatores associados. Jornal Brasileiro de Psiquiatria, 59(4), 286-292. doi: 10.1590/S004720852010000400004

Sowislo, J. F., \& Orth, U. (2013). Does low self-esteem predict depression and anxiety? A meta-analysis of longitudinal studies. Psychological Bulletin, 139(1), 213-240. doi: 10.1037/ a0028931.

Steiger, A. E., Allemand, M., Robins, R. W., \& Fend, H. A. (2014). Low and decreasing self-esteem during adolescence predict adult depression two decades later. Journal of Personality and Social Psychology, 106(2), 325-338. doi: 10.1037/a0035133

Steinberg, L., \& Lerner, R. M. (2004). The scientific study of adolescence: A brief history. The Journal of Early Adolescence, 24(1), 45-54. doi: 10.1177/0272431603260879

Surjadi, F. F., Lorenz, F. O., Wickrama, K. A. S, \& Conger, R. D. (2011). Parental support, partner support, and the trajectories of mastery from adolescence to early adulthood. Journal of Adolescence, 34, 619-628. doi: 10.1016/j. adolescence.2010.10.001 
Veselska, Z., Geckova, A. M., Orosova, O., Gajdosova, B., VanDijk, Wagner, A., Ribeiro, L. S., Arteche, A. X., \& Bernholdt, E. A. J. P., \& Reijneveld, S. A. (2009). Self-esteem and resilience: The connection with risk behavior among adolescents. Addictive Behaviors, 34, 287-291. doi: 10.1016/j.addbeh.2008.11.005.

(1999). Configuração familiar e o bem-estar psicológico dos adolescentes. Psicologia: Reflexão e Crítica, 12(1), 147-156. doi: 10.1590/S0102-79721999000100010

Von Soest, T., Wichstrøm, L., \& Kvalem, I. L. (2016). The development of global and domain-specific self-esteem from age 13 to 31. Journal of Personality and Social Psychology, 110(4), 592-608. doi: 10.1037/pspp0000060

Wagner, A., \& Levandowski, D. C. (2008). Sentir-se bem em família: Um desafio frente à diversidade. Revista Textos \& Submitted: 19/06/2017 Contextos, 7(1), 88-97.

Reviewed: 04/01/2018

Acccepted: 22/01/2018 